\title{
SPECIES RICHNESS AND DIVERSITY RELATED \\ TO ANTHROPOGENIC SOIL DISTURBANCE IN ABANDONED MEADOWS IN THE BIESZCZADY MTS. (EASTERN CARPATHIANS)
}

\author{
JOANNA KORZENIAK \\ Institute of Nature Conservation, Polish Academy of Sciences \\ Mickiewicza 33, 31-120 Kraków, Poland \\ e-mail: korzeniak@iop.krakow.pl
}

(Received: February 5, 2004. Accepted: October 10, 2004)

\begin{abstract}
The study was focused on soil factors influencing species richness and diversity after disturbance of the substrate followed by abandonment. Two types of disturbances in the past were considered: the removal of trees and shrubs with the resulting major destruction of soils, and deep ploughing. As a control meadows not covered by any management schemes for 50 years were studied. The topsoil stripping resulted in decrease of potassium, nitrogen and organic carbon contents, while deep ploughing caused less radical effects. Simultaneously, disturbances of the soil delayed the course of succession, and brought increase in species. The most species-rich are ploughed meadows. No differences in terms of species diversity, domination and evenness between the forms of disturbances were identified. However, there were groups of species indicative for soil disturbances. Analysis of the relationships between vegetation differentiation and the properties of soil suggests that available phosphorus may affect species richness and diversity in mountain meadows.
\end{abstract}

KEY WORDS: anthropogenic effects, floristic richness, mountain meadows, soil nutrients, Biosphere Reserve "Eastern Carpathians".

\section{INTRODUCTION}

As a result of a slump in agriculture, the meadows in the Carpathians are undergoing rapid and adverse alterations involving both a decrease in the number of species and the disappearance of specific combination of species. For this reason, the studies in these communities aim mainly at finding the most appropriate method of management (Michalik 1990; Zarzycki 1999; Ružičková et al. 2001). But apart from land use, one of the key factors that shape vegetation is disturbance regime (Armesto and Pickett 1985; McIntyre et al. 1995; Kotanen 1996; Wilby and Brown 2001). According to Denslow (1980) vegetation diversity depends on the evolutionary past of a given area and on the nature of alterations. The community abounds most in those species which are adapted to life on the patches representing the most frequent type of disturbance. Impact on vegetation is particularly strong and long-lasting when the disturbances cause serious changes in the substrate and in the abiotic properties of habitats. Removing the top layer of the soil or even the litter layer only, is of major importance to the species composition of communities (Hobbs and Huenneke 1992; McIntyre 2001). This practice is sometimes recommended in order to increase the number of species in meadows under intensive management (Berendse et al. 1992).
The meadows in the lower mountain zone in the Western Bieszczady Mts. (a western edge of the Eastern Carpathians) are typical anthropogenic semi-natural ecosystems, noted for their floristic and phytocoenotic richness (Denisiuk and Korzeniak 1999; Zemanek and Winnicki 1999). In the second half of the 1980's, some areas in the Bieszczady Mts. were subject to dramatic anthropogenic disturbances of the substrate resulting from the use of explosives to remove trees and shrubs and very deep ploughing. The degradation of soils was so serious that, despite an almost two-decade long process of regenerative succession, the vegetation still bears traces of these already 'historical' alterations.

The aim of this study was to find in what way the anthropogenic disturbances of the soil have affected the vegetation heterogeneity in the mountain meadows; which of the habitat factors were altered most and what is their possible correlation with the basic measures of species diversity. Given that the high levels of nutrients (particularly of $\mathrm{N}$, $\mathrm{P}$ and $\mathrm{K}$ ) do not favour species richness nor species diversity (Carson and Barrett 1988; Carson and Pickett 1990; Grime 1973, 2001; Tilman 1984, 1987, 1988; Wedin and Tilman 1996; Wilson and Tilman 2002), the following hypotheses were formulated: (1) strong, single disturbance of the soil in the past, destruction or disturbance of humus la- 
yer, should result in a decrease in nutrient contents compared with undisturbed meadows, and (2) patches with disturbed soil should show a higher diversity of vegetation than undisturbed sites.

For the purpose of this study, the anthropogenic disturbance is any event resulting from human activities which disturbed (or still disturbs) the structure of the ecosystem or of phytocoenosis and modified (or still modifies) the abiotic environment and the availability of nutrients (Pickett and White 1985; Łaska 2001).

\section{MATERIALS AND METHODS}

\section{Study area}

The studies were conducted on meadows in the Wołosatka stream valley in the Bieszczadzki National Park (SE Poland, Biosphere Reserve "Eastern Carpathians"), in a lower part of the beech forest zone (730-880 $\mathrm{m}$ a.s.1.) on ca. 650 hectares. The geological substrate is flysch (shales and sandstones of the Przeddukielska Nappe), with eutric cambisols and gleyic cambisols as predominating soils. Dystric cambisols occur only locally on the upper slopes of the valley (Skiba et al. 1998). The climate is of a mountain type with strong continental features. The annual average air temperature in the valley ranges from +4 to $+6^{\circ} \mathrm{C}$, the estimated annual average precipitation in the Bieszczady Mts. is $1000-1300 \mathrm{~mm}$ (Nowosad 1995).

After World War II agricultural management in the valley declined rapidly. Former meadows and pastures underwent spontaneous secondary succession. In 1987 trees and shrubs were cleared from a part of the area in order to establish highly productive permanent grassland operations. Explosives and heavy military equipment were used, which resulted in long-lasting alterations in the environment (Table 1). Since 1991, this part of the valley has not been cultivated in any way.

The vegetation in the study area is a mosaic of non-forest communities at various stages of succession. The most widespread is Agrostietum capillaris of Arrhenatherion alliance. It occurs in variants with Hypericum maculatum, Holcus mollis, Deschampsia caespitosa or Nardus stricta. Short grassland with Festuca rubra and sward with Nardus stricta from Nardetalia order are also common. As a result of progressive secondary succession, the area of meadows has decreased gradually overgrown by Betula pendula, Salix sp., Juniperus communis and Alnus incana (the nomenc- lature used follows 'Flowering plants and pteridophytes of Poland. A checklist (Mirek et al. 2002)).

\section{Sample collection}

The studies were carried out over three years (19992001) on 77 permanent plots within three types of abandoned meadows: (1) Co - without soil disturbances (21 plots), 2) Ex - area where shrubs were removed with the use of explosives (23 plots), 3) $\mathrm{Pl}$ - patches which, after removal of trees and shrubs, were ploughed to a depth of 90 $\mathrm{cm}$ (33 plots). As these forms of degradation involved almost the entire slopes of the valley up to the tree line, the study plots were laid out along the transects, running through possibly homogenous patches, from the tree line in the direction of the valley bottom, up to a place with a manifest change, e.g. transition of fresh meadows into tall herb communities or mires. The beginning of each transect was marked in the field. Then, along the selected azimuth, in 25-m intervals, $10 \times 10 \mathrm{~m}$ study plots were established. Each year, in the period of optimum vegetation development (July), on each plot a relevee was conducted in percentage scales. The cover by species was estimated within $10 \%$ intervals, with species with cover below $1 \%$ included in a separate category. For lichens and mosses, estimates were limited only to cover for the whole layer without identifying species.

In order to determine the basic properties of the soil, in 1999 from the centre of each plot one sample of the top layer (up to $15 \mathrm{~cm}$ ) was collected. The soil sample analyses included: $\mathrm{pH}$ in water by the potentiometric method, organic $\mathrm{C}$ contents by the Tiurin method as modified by Oleksynowa, total $\mathrm{N}$ by the Kjeldahl method, contents of available $\mathrm{P}$ and $\mathrm{K}$ forms by the Egner-Riehm method, and of $\mathrm{Mg}$ - by the Schachtschabel method. The rate of organic matter decomposition was evaluated by $\mathrm{C}$ : $\mathrm{N}$ ratio.

\section{Data analysis}

Using the data from the relevees, the following parameters were determined for each plot:

1) $S$ - number of species in the sample (species richness); 2) $H^{\prime}$ - Shannon-Wiener index of species diversity (Magurran 1988):

$$
H^{\prime}=\underset{i=1}{\substack{S \\ i=1}} \ln p_{i}
$$

where: $p_{i}-$ share (here: cover) by $\mathrm{i}$-th species in the sample;

TABLE 1. Types of human-induced disturbances and their effect on the topography observed in the field.

\footnotetext{
Type of disturbance

Co - control (no anthropogenic disturbance) $\quad \mathrm{Pl}-$ deep ploughing
}

Ex - clearings with topsoil stripping (with explosives)
Alterations to the soil no changes upturned upper horizons of the soil profile - humus horizon under mineral-weathering horizon destruction of the upper horizons of the soil profile, skeleton on the surface, long-term soil erosion

Microtopography

slightly undulating

deep parallel furrows

undulating with depressions about $0.5 \mathrm{~m}$ deep

Plant cover 
3) $\lambda$-Simpson's domination index (Magurran 1988):

$$
\lambda=\sum_{i=1}^{S}\left(p_{i}^{2}\right)
$$

4) $E$ - evenness index (Magurran 1988):

$$
E=H^{\prime} / H_{\max } \text { where } H_{\text {max }}=\ln S .
$$

The variability in the number of species $(S)$ between the types of disturbances defined, was determined by one-way ANOVA. In cases of $H^{\prime}, \lambda$ and $E$, which did not show normal distribution, the Kruskal-Wallis test was used. The same tests were used to compare soil conditions in meadows subjected to various anthropogenic effects. In cases of variables deviating from normal distribution logarithmic transformation $(\mathrm{pH}$ in water, the contents organic $\mathrm{C}, \mathrm{P}$ and $\mathrm{K}$ ) or square root transformation (total $\mathrm{N}$ ) was applied. The detailed comparison of the significance of differences in groups was made with a posteriori Scheffé's test. The correlations between abiotic environmental factors and the heterogeneity of vegetation were tested by the Pearson's linear correlation method or Spearman's rank correlation. All statistical calculations were carried out using the STATISTICA software package (StatSoft, Inc. 1997).

\section{RESULTS}

Diversity measures and species composition in disturbed meadows

Over a period of three years, a total of 218 species of vascular plants were found in all study plots. The meadows disturbed in various ways did not differ much in terms of the cumulative species richness i.e. species number in the first year plus new species appearing in later years (in Co meadows 180 species occurred, in $\mathrm{Pl}-189$, and in Ex meadows - 172 species). The type of disturbance affected significantly the average number of species per $100 \mathrm{~m}^{2}$ (ANOVA df=2.207; $\mathrm{F}=7.08 ; \mathrm{p}=0.001$ ). The most speciesrich meadows (after deep ploughing) differed both from undisturbed meadows $(\mathrm{p}=0.003)$ and from those where shrubs were cleared $(p=0.028)$, in Scheffe's test. From the viewpoint of species diversity, evenness and domination, there are no differences between the forms of disturbances studied (Table 2).

Meadows subjected to various types of anthropogenic impact differ in their floristic composition. Patches from which shrubs were cleared are distinct for the high abundance of species from Nardo-Callunetea class (Table 3). Synanthropic and ruderal taxa are rare (only 14 species were found) and occur more frequently on the plots after the soil disturbances. The characteristic species of patches with barren soil are: Corylus avellana, Rubus hirtus, Dianthus compactus and Hypericum perforatum (Table 4). Also Betula pendula and Alnus incana saplings occur abundantly. The group of species thriving better on ploughed plots includes: Listera ovata, Tussilago farfara, Hieracium umbellatum, some species of moist meadows and of genus Alchemilla. The species characteristic for habitats of disturbed soil are quite numerous (Rumex acetosella, Fragaria vesca, Succisa pratensis, Hieracium pilosella, Hypochoeris radicata), whereas there are no good indicators discriminating the long-term (i.e. fifty years') abandonment from the shorter (twenty years') one. Frequent occurrence of tree and bush saplings irrespective of the type of disturbance shows

TABLE 2. Species richness $S$, species diversity $H^{\prime}$, dominance $\lambda$ and evenness $E$ (mean $\pm \mathrm{SD}$ ) on plots undisturbed (Co), ploughed (Pl) and cleared (Ex) based on data 1999-2001. Different superscript letters indicate significant differences between the diversity characteristics of disturbance types as determi-

\begin{tabular}{|c|c|c|c|c|}
\hline Type of disturbance & $S$ & $H^{\prime}$ & $\lambda$ & $E$ \\
\hline $\mathrm{Co}$ & $54.04 \pm 10.74^{b}$ & $2.80 \pm 0.44$ & $0.11 \pm 0.09$ & $0.70 \pm 0.09$ \\
\hline $\mathrm{Pl}$ & $59.62 \pm 9.18^{\mathrm{a}}$ & $2.86 \pm 0.42$ & $0.10 \pm 0.06$ & $0.70 \pm 0.09$ \\
\hline Ex & $55.45 \pm 8.52^{b}$ & $2.84 \pm 0.29$ & $0.10 \pm 0.04$ & $0.71 \pm 0.05$ \\
\hline Statistical significance & $\begin{array}{c}\mathrm{F}_{2,207}=7.08 \\
\mathrm{p}=0.0011\end{array}$ & $\begin{array}{c}\mathrm{H}_{2,210}=3.92 \\
\text { ns }\end{array}$ & $\begin{array}{c}\mathrm{H}_{2,210}=2.10 \\
\text { ns }\end{array}$ & $\begin{array}{c}\mathrm{H}_{2,210}=0.62 \\
\mathrm{~ns}\end{array}$ \\
\hline
\end{tabular}
ned by one-way ANOVA or Kruskal-Wallis test $(\mathrm{p}<0.05)$.

TABLE 3. Comparison of phytosociological structure of different forms of disturbance. Means are shown with ranges in parentheses. P denotes the probability of difference according to Kruskal-Wallis test. Within the raw, values with the same superscript letter are not significantly different at $\mathrm{p}=0.017$ (ba-

\begin{tabular}{|c|c|c|c|c|}
\hline Characteristics & Co & $\mathrm{Pl}$ & Ex & $\mathrm{P}$ \\
\hline \multicolumn{5}{|l|}{ Number of species/100 $\mathrm{m}^{2}$} \\
\hline Molinio-Arrhenatheretea & $21.3(2-34)^{\mathrm{a}}$ & $22.7(10-36)^{a}$ & $15.8(5-31)^{b}$ & $<0.0001$ \\
\hline Nardo-Callunetea & $5.4(0-10)^{\mathrm{a}}$ & $6.9(3-12)^{b}$ & $8.4(5-12)^{c}$ & $<0.0001$ \\
\hline Betulo-Adenostyletea & $2.5(1-4)$ & $2.1(0-4)$ & $2.4(1-4)$ & ns \\
\hline Querco-Fagetea & $1.3(0-5)^{\mathrm{a}}$ & $0.6(0-3)^{b}$ & $1.4(0-5)^{\mathrm{a}}$ & $<0.0001$ \\
\hline Vaccinio-Piceetea & $1.1(0-3)^{\mathrm{a}}$ & $0.6(0-3)^{b}$ & $0.9(0-3)^{a b}$ & 0.02 \\
\hline Synanthropic & $1.4(0-4)^{\mathrm{a}}$ & $2.0(0-6)^{b}$ & $2.4(0-5)^{b}$ & 0.0001 \\
\hline \multicolumn{5}{|l|}{ Cover $(\%)$ of species } \\
\hline Molinio-Arrhenatheretea & $42.9(2-99)^{a b}$ & $45.2(9-90)^{\mathrm{a}}$ & $33.7(9-86)^{b}$ & 0.002 \\
\hline Nardo-Callunetea & $17.4(0-95)^{\mathrm{a}}$ & $15.5(1-57)^{a}$ & $23.2(3-62)^{b}$ & 0.0001 \\
\hline Betulo-Adenostyletea & $12.8(0-45)$ & $17.1(0-71)$ & $16.3(0-45)$ & ns \\
\hline Querco-Fagetea & $1.2(0-18)^{\mathrm{a}}$ & $0.2(0-4)^{b}$ & $2.6(0-75)^{a}$ & $<0.0001$ \\
\hline Vaccinio-Piceetea & $11.1(0-87)^{\mathrm{a}}$ & $0.5(0-6)^{b}$ & $1.0(0-8)^{\mathrm{ab}}$ & 0.001 \\
\hline Synanthropic & $1.4(0-15)^{\mathrm{a}}$ & $1.1(0-20)^{\mathrm{a}}$ & $1.8(0-15)^{b}$ & 0.0015 \\
\hline
\end{tabular}
sed on Kruskal-Wallis test, p level after Bonferroni correction). 
TABLE 4. Distribution (frequency of occurrence/\% mean cover) of nonubiquitous species on the plots. $+=$ cover values $<0.5 \%$; $*$ indicates synanthropic and ruderal species.

\begin{tabular}{|c|c|c|c|c|}
\hline & & Co & $\mathrm{Pl}$ & Ex \\
\hline \multicolumn{5}{|c|}{ Soil disturbance indicators } \\
\hline & Rumex acetosella & $-/-$ & $18 /+$ & $11 /+$ \\
\hline & Rumex crispus & $-/-$ & $11 /+$ & $11 /+$ \\
\hline & Succisa pratensis & $4 /+$ & $51 / 3$ & $28 / 1$ \\
\hline \multirow[t]{6}{*}{$*$} & Rhinanthus serotinus & $2 /+$ & $13 /+$ & $20 /+$ \\
\hline & Platanthera bifolia & $2 /+$ & $11 /+$ & $11 /+$ \\
\hline & Leontodon autumnalis & $4 /+$ & $22 /+$ & $27 /+$ \\
\hline & Hieracium pilosella & $5 /+$ & $42 / 1$ & $48 /+$ \\
\hline & Leontodon hispidus & $5 /+$ & $24 /+$ & $17 /+$ \\
\hline & Hypochoeris radicata & $7 /+$ & $26 /+$ & $53 / 2$ \\
\hline \multirow[t]{3}{*}{$*$} & Gnaphalium sylvaticum & $9 /+$ & $42 /+$ & $73 /+$ \\
\hline & Hieracium laevigatum & $9 /+$ & $50 /+$ & $42 /+$ \\
\hline & Danthonia decumbens & $11 /+$ & $31 /+$ & $52 / 2$ \\
\hline \multirow[t]{7}{*}{$*$} & Fragaria vesca & $18 /+$ & $46 / 1$ & $61 / 1$ \\
\hline & Barren soil preferrers & & & \\
\hline & Rubus hirtus & $5 /+$ & $2 /+$ & $70 / 3$ \\
\hline & Dianthus compactus & $9 /+$ & $10 /+$ & $70 / 2$ \\
\hline & Corylus avellana (b) & $-/-$ & $-/-$ & $22 /+$ \\
\hline & Hypericum perforatum & $4 /+$ & $4 /+$ & $27 /+$ \\
\hline & Carlina acaulis & $4 /+$ & $9 /+$ & $27 /+$ \\
\hline \multirow[t]{4}{*}{ * } & Pastinaca sativa & $-/-$ & $-/-$ & $8 /+$ \\
\hline & Euphorbia serrulata & $-/-$ & $-/-$ & $8 /+$ \\
\hline & Trifolium aureum & $-/-$ & $1 /+$ & $6 /+$ \\
\hline & Thesium alpinum & $-/-$ & $-/-$ & $5 /+$ \\
\hline \multirow[t]{3}{*}{$*$} & Centaurium erythrea & $-/-$ & $-/-$ & $5 /+$ \\
\hline & Deep ploughing preferrers & & & \\
\hline & Listera ovata & $-/-$ & $18 /+$ & $-/-$ \\
\hline \multirow[t]{11}{*}{$*$} & Tussilago farfara & $-/-$ & $14 /+$ & $-/-$ \\
\hline & Hieracium umbellatum & $-/-$ & $10 /+$ & $-/-$ \\
\hline & Epilobium palustre & $-/-$ & $10 /+$ & $-/-$ \\
\hline & Alchemilla acutiloba & $5 /+$ & $44 /+$ & $19 /+$ \\
\hline & Alchemilla monticola & $11 /+$ & $44 /+$ & $16 /+$ \\
\hline & Alchemilla glabra & $2 /+$ & $40 / 1$ & $8 /+$ \\
\hline & Juncus conglomeratus & $5 /+$ & $29 /+$ & $8 /+$ \\
\hline & Galeopsis bifida & $7 /+$ & $32 / 1$ & $5 /+$ \\
\hline & Cynosurus cristatus & $4 /+$ & $19 /+$ & $6 /+$ \\
\hline & Taraxacum officinale & $9 /+$ & $16 /+$ & $5 /+$ \\
\hline & Potentilla anserina & $-/-$ & $9 /+$ & $3 /+$ \\
\hline \multirow[t]{23}{*}{ * } & Cirsium arvense & $9 /+$ & $22 /+$ & $-/-$ \\
\hline & Alchemilla crinita & $2 /+$ & $18 /+$ & $-/-$ \\
\hline & \multicolumn{4}{|l|}{ Trees and shrubs } \\
\hline & Betula pendula & $46 / 1$ & $54 /+$ & $83 / 3$ \\
\hline & Salix capraea & $27 /+$ & $61 /+$ & $70 /+$ \\
\hline & Juniperus communis & $21 / 1$ & $37 /+$ & $38 /+$ \\
\hline & Picea abies & $34 /+$ & $33 /+$ & $27 /+$ \\
\hline & Alnus incana & $25 / 1$ & $19 /+$ & $30 / 2$ \\
\hline & Salix cinerea & $16 /+$ & $27 /+$ & $20 /+$ \\
\hline & Frangula alnus & $29 /+$ & $6 /+$ & $20 /+$ \\
\hline & Acer pseudoplatanus & $20 /+$ & $4 /+$ & $19 /+$ \\
\hline & Rosa canina & $7 /+$ & $12 /+$ & $20 /+$ \\
\hline & Salix aurita & $9 /+$ & $13 /+$ & $11 /+$ \\
\hline & Sorbus aucuparia & $5 /+$ & $4 /+$ & $20 /+$ \\
\hline & Salix silesiaca & $2 /+$ & $7 /+$ & $9 /+$ \\
\hline & Populus tremula & $36 / 1$ & $33 /+$ & $-/-$ \\
\hline & Larix decidua & $9 /+$ & $7 /+$ & $-/-$ \\
\hline & Pinus sylvestris & $4 /+$ & $6 /+$ & $-/-$ \\
\hline & Fagus sylvatica & $7 /+$ & $-/-$ & $6 /+$ \\
\hline & Viburnum opulus & $2 /+$ & $-/-$ & $11 /+$ \\
\hline & Crataegus monogyna & $4 /+$ & $-/-$ & $5 /+$ \\
\hline & Prunus spinosa & $9 /+$ & $-1-$ & $-/-$ \\
\hline & Sambucus racemosa & $4 /+$ & $-1-$ & $-/-$ \\
\hline
\end{tabular}

quite rapid progressive changes in the course of secondary succession.

\section{Effect of ploughing and topsoil stripping on soil properties}

The meadows with disturbed substrate are characterised by significantly lower contents of organic $\mathrm{C}$, total $\mathrm{N}$ and available $\mathrm{K}$ in the soil (Table 5).

A detailed analysis of the significance of differences, by a posteriori Scheffé's test, shows that soils in undisturbed meadows are richer in organic $\mathrm{C}$ than soils of ploughed meadows $(p=0.04)$ and those with shrubs cleared $(\mathrm{p}=0.009)$. They also contain more total $\mathrm{N}$ and $\mathrm{K}$ than the soils of meadows with shrubs cleared $(\mathrm{p}=0.02$ and 0.002 respectively).

\section{Vegetation diversity and selected habitat factors}

Irrespective of the degree of modification of the soil, significant but rather weak correlations with species richness appeared only with regard to soil reaction and the contents of available P (Fig. 1). The relationships between particular indices of vegetation diversity and properties of the soil are different for each type of disturbance (Table 6). The effect of $\mathrm{P}$ on species richness, diversity and evenness depends on its contents in the soil. Whenever soils are relatively richer in $\mathrm{P}$ (Co and $\mathrm{Pl}$ meadows), there is a negative correlation between levels of $\mathrm{P}$ and $S$. On the poorest soils (Ex meadows), where $\mathrm{P}$ deficiency may be an essential limiting factor of vegetation growth, correlations of $\mathrm{P}$ contents with $H^{\prime}$ and $E$ are positive. The same correlation occurs between $\mathrm{K}$ content and evenness. The relationship between the heterogeneity of vegetation and total $\mathrm{N}$ content, was shown only in undisturbed meadows of which the soils are relatively rich in this element $\left(r_{S}=-0.569, N=21, p=0.017\right.$; Table 6).
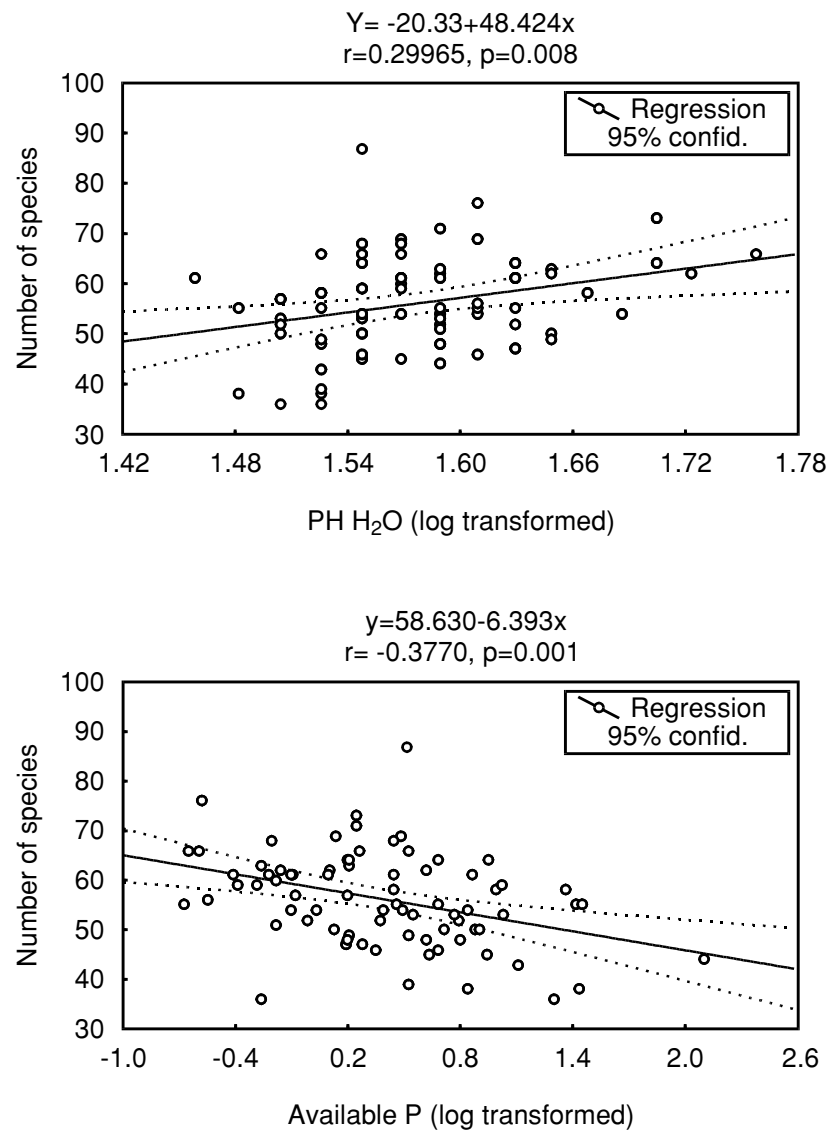

Fig. 1. Result of linear regression of species richness on soil $\mathrm{pH}$ and soil concentration of $\mathrm{P}$ 
TABLE 5. Soil chemistry (mean \pm SD) of samples taken in 1999 from topsoil on undisturbed (Co), deep ploughed (Pl) and cleared with explosives (Ex) meadows - results of one-way ANOVA and Kruskal-Wallis test. Means accompanied by the same letter were not significantly different ( $\alpha=0.05)$.

\begin{tabular}{|c|c|c|c|c|c|c|c|}
\hline & $\mathrm{Co}$ & $\mathrm{Pl}$ & Ex & $F$ & $H$ & $d f$ & $p$ \\
\hline $\mathrm{pH}\left(\mathrm{H}_{2} \mathrm{O}\right)$ & $4.92 \pm 0.31$ & $4.88 \pm 0.31$ & $4.78 \pm 0.25$ & 1.44 & - & 2,71 & ns \\
\hline$C$ organic $[\mathrm{g} / 100 \mathrm{~g}]$ & $3.49 \pm 0.94^{\mathrm{a}}$ & $2.86 \pm 0.90^{b}$ & $2.64 \pm 0.68^{b}$ & 5.51 & - & 2,71 & $* *$ \\
\hline total $\mathrm{N}[\mathrm{g} / 100 \mathrm{~g}]$ & $0.38 \pm 0.09^{a}$ & $0.32 \pm 0.08 \mathrm{ab}$ & $0.30 \pm 0.07^{b}$ & 4.44 & - & 2,71 & $*$ \\
\hline $\mathrm{C}: \mathrm{N}$ & $9.45 \pm 2.38$ & $8.85 \pm 1.30$ & $8.62 \pm 0.60$ & - & 1.67 & 2,74 & ns \\
\hline $\mathrm{P}_{2} \mathrm{O}_{5}[\mathrm{mg} / 100 \mathrm{~g}]$ & $1.91 \pm 0.91$ & $1.71 \pm 1.02$ & $1.34 \pm 0.64$ & 2.51 & - & 2,70 & ns \\
\hline $\mathrm{K}_{2} \mathrm{O}[\mathrm{mg} / 100 \mathrm{~g}]$ & $10.98 \pm 5.73^{\mathrm{a}}$ & $7.01 \pm 3.23 b$ & $6.30 \pm 2.39^{b}$ & 7.76 & - & 2,71 & $* * *$ \\
\hline $\mathrm{MgO}[\mathrm{mg} / 100 \mathrm{~g}]$ & $1.76 \pm 2.12$ & $2.89 \pm 4.12$ & $2.35 \pm 2.94$ & - & 0.38 & 2,73 & ns \\
\hline
\end{tabular}

$* * *-\mathrm{p}<0.001 ; * *-\mathrm{p}<0.01 ; *-\mathrm{p}<0.05 ; \mathrm{ns}-$ not significant

TABLE 6. Correlation between species richness $S$, Shannon's diversity index $H^{\prime}$, dominance index $\lambda$, evenness index $E$ and soil chemistry on undisturbed (Co), deep ploughed (Pl) and cleared (Ex) meadows.

\begin{tabular}{|c|c|c|c|c|c|c|c|c|}
\hline & & $\mathrm{pH}\left(\mathrm{H}_{2} \mathrm{O}\right)$ & C org. & total $\mathrm{N}$ & $\mathrm{C}: \mathrm{N}$ & $\mathrm{P}_{2} \mathrm{O}_{5}$ & $\mathrm{~K}_{2} \mathrm{O}$ & $\mathrm{MgO}$ \\
\hline \multirow[t]{3}{*}{$S$} & Co & 0.408 & -0.064 & 0.001 & -0.103 & $-0.543^{*}$ & -0.429 & 0.129 \\
\hline & $\mathrm{Pl}$ & 0.177 & 0.294 & 0.343 & 0.089 & $-0.542 *$ & 0.030 & 0.014 \\
\hline & Ex & 0.390 & 0.119 & 0.166 & 0.274 & 0.167 & 0.184 & -0.036 \\
\hline \multirow[t]{3}{*}{$H^{\prime}$} & $\mathrm{Co}$ & 0.380 & -0.328 & $-0.569 *$ & -0.07 & -0.396 & 0.022 & 0.449 \\
\hline & $\mathrm{Pl}$ & 0.340 & 0.365 & 0.346 & 0.251 & $-0.549 *$ & 0.050 & 0.175 \\
\hline & Ex & 0.394 & 0.308 & 0.253 & 0.496 & $0.516^{*}$ & 0.487 & -0.318 \\
\hline \multirow[t]{3}{*}{$\lambda$} & Co & -0.385 & 0.298 & 0.473 & 0.036 & 0.364 & 0.182 & -0.393 \\
\hline & Pl & -0.274 & -0.371 & -0.362 & -0.256 & 0.326 & -0.293 & -0.230 \\
\hline & Ex & -0.418 & -0.220 & -0.201 & -0.330 & -0.312 & -0.333 & 0.072 \\
\hline \multirow[t]{3}{*}{$E$} & $\mathrm{Co}$ & 0.361 & -0.347 & $-0.645 *$ & -0.055 & -0.269 & 0.223 & 0.406 \\
\hline & Pl & 0.422 & 0.394 & 0.312 & 0.367 & $-0.507 *$ & 0.032 & 0.280 \\
\hline & Ex & 0.290 & 0.302 & 0.239 & 0.459 & $0.610^{*}$ & $0.548 *$ & -0.331 \\
\hline
\end{tabular}

* - statisticaly significant (Spearman rank correlation, $\mathrm{p}=0.017$ after Bonferroni correction)

No relationship was found between the soil reaction, organic matter content, its rate of decomposition $(\mathrm{C}: \mathrm{N})$, content of available $\mathrm{Mg}$ and any of the variables illustrating the heterogeneity of vegetation.

\section{DISCUSSION}

The results of the study only partly support the two hypotheses. The decrease in nutrient resources related to past destruction of the soil, which was already poor, did not appear to be as manifest as expected. The removing of the topsoil caused intensive erosion and surface runoff and resulted in the long-term reduction of resources, particularly of $\mathrm{K}$, organic $\mathrm{C}$ and $\mathrm{N}$. Deep ploughing turned out to be less radical in terms of its effects: meadows subjected to deep ploughing appear similar to the control (undisturbed) plots as far as $\mathrm{N}$ contents are concerned.

The presumption that species diversity in meadows on disturbed substrate will be higher than that in patches left without intervention was also only partly confirmed. Almost two decades after the disturbance no significant differences were found in species diversity, evenness and domination. Only in terms of number of species, which is the simplest measure of vegetation diversity, were the meadows subjected to deep ploughing more rich than other meadows. The high species richness of studied meadows (from 21 to 87 species per plot; 57 species $/ 100 \mathrm{~m}^{2}$ on average) is also related to their abandonment. Certainly, disturbances had interrupted the process of secondary succes- sion and delayed it. Ploughed and shrub cleared patches are now at the intermediate stage of succession, which is usually characterized by the highest species diversity (Faliński 1998). The similar share of tree saplings in floristic composition of undisturbed and disturbed patches indicates that recolonization after soil degradation proceeded quite rapidly. Dispersion of species was facilitated by lack of isolation, while cessation of any agriculture activities resulted in small share of synanthropic species, usually considered as disturbance indicators.

Some relationships between vegetation differentiation and habitat factors were observed. The positive correlation of species richness and the soil reaction results from the fact that $\mathrm{pH}$ strongly affects the availability of $\mathrm{P}, \mathrm{N}$ and $\mathrm{K}$ to plants. A significant, negative correlation occurs between $\mathrm{P}$ contents and $H^{\prime}$ and $E$ in undisturbed or deeply ploughed meadows. No effects have been found, however between the $\mathrm{P}$ content and domination index. Only in meadows with the shrubs cleared, where the soil is particularly low in nutrients, does a high $\mathrm{P}$ level support species diversity, as well as most likely being a limiting factor.

A negative correlation between the $\mathrm{P}$ level and the number of species was reported in old permanent grasslands (Janssens et al. 1998). Also Gough and Marrs (1990) suggest that in many semi-natural meadow communities, low contents of available $\mathrm{P}$ in the soil is the main factor limiting the occurrence of species-rich habitats, whereas the $\mathrm{N}$ level is not of major importance. In contrast to nitrogen, which is present in the soil almost entirely in organic form, $\mathrm{P}$ occurs also in mineral form and is definitely a less mobi- 
le element than N. It should thus be expected that the destruction of topsoil would entail a significant and fairly permanent loss of P. However, the soil in disturbed and undisturbed meadows do not differ in the contents of available $\mathrm{P}$, but on the other hand, the plots within the areas subjected to the same disturbance show a great variability (SD value - Table 5).

Low $\mathrm{P}$ contents may limit the rate of $\mathrm{N}$ mineralisation and of $\mathrm{N}$ fixation by legumes, i.e. limit the supplies from two principal sources (Janssens et al. 1998). In the study plots, the average cover by legumes per $100 \mathrm{~m}^{2}$ is ca. $8 \%$. Almost $60 \%$ of cover by all species of Fabaceae is by Trifolium medium, ca. $20 \%$ by Vicia cracca, with fairly large proportions of Lathyrus pratensis, T. hybridum and Vicia sepium. No relationships between the occurrence of legumes and $\mathrm{N}$ contents or mineralisation rate for organic matter were found. The number of occurrences of leguminous species (but not their cover) was indeed dependant on $P$ contents $\left(r_{S}=0.325, N=76, p=0.004\right)$. The interaction between $\mathrm{P}$ and $\mathrm{N}$ is very likely but proving this is fraught with major difficulties (Janssens et al. 1998).

The correlation between vegetation diversity and one of the basic nutrients i.e. nitrogen, was identified only in undisturbed meadows. Brożek (1993) found that on abandoned lands in the Bieszczady Mts. dense stands of symbiotic nitrogen-fixing Alnus incana caused $\mathrm{N}$ and organic matter enrichment. However, on the study plots with Alnus incana contents of nitrogen did not differ from the mean value for the given form of disturbance or was even lower. Relatively high levels of $\mathrm{N}$ in undisturbed plots probably result from an increase of total soil nitrogen during succession. This pattern of successional changes was observed on nutrient-poor soils (Gleeson and Tilman 1990; Dzwonko and Loster 1996).

The results of this study suggest that strong and longterm alteration of soil properties and changes during the course of succession resulting from disturbance in the soil is an important factor favouring species richness. However, the persistence of vegetation pattern of high alfa and betadiversity is difficult to estimate without long-term studies.

\section{ACKNOWLEDGEMENTS}

Funding for this research was provided by the State Committee for Scientific Research (KBN grant no. 6PO4G 01016). I am grateful to A. Kalemba for the on-site assistance and to M. Drewnik and T. Zaleski for soil chemical analysis. I thank also S. Michalik, R. Kaźmierczakowa, T. Zając, P. Olejniczak and W. Bąba who provided valuable comments and suggestions to the manuscript.

\section{LITERATURE CITED}

ARMESTO J.J., PICKETT S.T.A. 1985. Experiments on disturbance in old-field plant communities: impact on species richness and abundance. Ecology 66: 230-240.

BERENDSE F., OOMES M.J.M., ALTENA H.J., ELBERSE W.TH. 1992. Experiments on the restoration of species-rich meadows in the Netherlands. Biol. Conserv. 62: 59-65.

BROŻEK S. 1993. Przekształcanie górskich gleb porolnych przez olszę szarą Alnus incana (L.) Moench [Soil changes caused by grey alder Alnus incana (L.) Moench on farm abandoned lands in Carpathians]. Zesz. Nauk. AR w Krakowie, Rozprawy habi- litacyjne 184: 1-52 (in Polish with English summary).

CARSON W.P., BARRETT G.W. 1988. Succession in old-field plant communities, effect of contrasting types of nutrient enrichment. Ecology 69: 984-994.

CARSON W.P., PICKETT S.T.A. 1990. Role of resources and disturbance in the organization of an old-field plant community. Ecology 71: 226-238.

DENISIUK Z., KORZENIAK J. 1999. Zbiorowiska nieleśne krainy dolin Bieszczadzkiego Parku Narodowego [Non-forest plant communities of the lower forest zone in the Bieszczady National Park]. Monografie Bieszczadzkie 5: 1-161 (in Polish with English summary).

DENSLOW J.S. 1980. Patterns of plant species diversity during succession under different disturbance regime. Oecologia 46: 18-21.

DZWONKO Z., LOSTER S. 1996. Effects of dominant trees and anthropogenic disturbances on secondary succession and vegetation differentiation in the suburban landscape of Kraków. Ochr. Przyr. 53: 3-17 (in Polish with English summary).

FALIŃSKI J.B. 1998. Dioecious woody pioneer species (Juniperus communis, Populus tremula, Salix sp. div.) in the secondary succession and regeneration. Phytocoenosis 10 (N.S.) Suppl. Cartogr. Geobot. 8: 1-156.

GLEESON S.K., TILMAN D. 1990. Allocation and the transient dynamics of succession on poor soils. Ecology 71: 1144-1155.

GOUGH M.W., MARRS R.H. 1990. A comparison of soil fertility between semi-natural and agricultural plant communities, implications for the creation of species-rich grasslands on abandoned agricultural land. Biol. Conserv. 51: 83-96.

GRIME J.P. 1973. Control of species density in herbaceous vegetation. J. Environ. Management 1: 151-167.

GRIME J.P. 2001. Plant strategies, vegetation processes, and ecosystem properties. $2^{\text {nd }}$ ed. J. Wiley and Sons, Chichester, New York, Weinheim, Brisbane, Singapore, Toronto. 417 p.

HOBBS R.J., HUENNEKE L.F. 1992. Disturbance, diversity, and invasion, implications for conservation. Conserv. Biology 6: 324-337.

JANSSENS F., PEETERS A., TALLOWIN J.R.B., BAKKER J.P., BEKKER R.M., FILLAT F., OOMES M.J.M. 1998. Relationship between soil chemical factors and grassland diversity. Plant Soil 202: 69-78.

KOTANEN P.M. 1996. Revegetation following soil disturbance in a California meadow, the role of propagule supply. Oecologia 108: 652-662.

ŁASKA G. 2001. The disturbance and vegetation dynamics, a review and an alternative framework. Plant Ecology 157: 77-99.

MAGURRAN A.E. 1988. Ecological diversity and its measurements. Croom Helm Ltd., London, UK. 179 p.

McINTYRE S. 2001. Biophysical and human influences on plant species richness in grasslands, comparing variegated landscapes in subtropical and temperate regions. Austral Ecology 26: 233-245.

McINTYRE S., LAVOREL S., TREMONT R.M. 1995. Plant life-history attributes, their relationship to disturbance response in herbaceous vegetation. J. Ecol. 83: 31-44.

MICHALIK S. 1990. Secondary succession and problems in the preservation of semi-natural biocenoses in national parks and nature reserves. Prądnik, Prace Muz. Szafera 2: 175-198 (in Polish with English summary).

MIREK Z., PIĘKOŚ-MIRKOWA H., ZAJĄC A., ZAJĄC M. 2002. Flowering plants and pteridophytes of Poland. A checklist. Biodiversity of Poland, vol. 1: 1-442. W. Szafer Institute of Botany, Polish Academy of Sciences, Kraków.

NOWOSAD M. 1995. Zarys klimatu Bieszczadzkiego Parku Narodowego i jego otuliny w świetle dotychczasowych badań [Outlines of climate of the Bieszczady National Park and its buffer zone in the light of previous studies]. Roczniki Bieszczadzkie 4: 163-183 (in Polish with English summary).

PICKETT S.T.A., WHITE P. 1985. The ecology of natural disturbance and patch dynamics. Academic Press, Orlando, FL. 472 p. 
RUŽIČKOVÁ H., HALADA L', DAVID S., GERHÁTOVÁ K. 2001. Management of meadows in the Biosphere Reserve East Carpathians. II. Results after 7 years. Ekológia (Bratislava) 20, suppl. 3/2001: 76-87.

SKIBA S., DREWNIK M., PRĘDKI R., SZMUC R. 1998. Gleby Bieszczadzkiego Parku Narodowego [Soils of the Bieszczady National Park]. Monografie Bieszczadzkie 2: 1-88. (in Polish with English summary)

StatSoft, Inc. 1997. STATISTICA for Windows (Computer program manual). Tulsa, OK, StatSoft, Inc., 2300 East 14-th Street, Tulsa.

TILMAN D. 1984. Plant dominance along an experimental nutrient gradient. Ecology 65: 1445-1453.

TILMAN D. 1987. Secondary succession and the pattern of plant dominance along experimental nitrogen gradients. Ecol. Monogr. 57: 189-214.

TILMAN D. 1988. Plant strategies and the dynamics and structure of plant communities. Princeton University Press, Princeton, New Jersey, USA. 376 p.
WEDIN D.A., TILMAN D. 1996. Influence of nitrogen loading and species composition on the carbon balance of grasslands. Science 274: 1720-1723.

WILBY A., BROWN V.K. 2001. Herbivory, litter and soil disturbance as determinant of vegetation dynamics during early oldfield succession under set-aside. Oecologia 127: 259-265.

WILSON S.D., TILMAN D. 2002. Quadratic variation in oldfield species richness along gradient of disturbance and nitrogen. Ecology 83: 492-504.

ZARZYCKI J. 1999. Ekologiczne podstawy kształtowania ekosystemów łąkowych Babiogórskiego Parku Narodowego. Studia Nat. 45: 1-97. (in Polish with English summary)

ZEMANEK B., WINNICKI T. 1999. Rośliny naczyniowe Bieszczadzkiego Parku Narodowego [Vascular plants of the Bieszczady National Park]. Monografie Bieszczadzkie 3: 1-249. (in Polish with English summary) 